Article

\title{
Proximate Composition and Nutritional Value of Three Macroalgae: Ascophyllum nodosum, Fucus vesiculosus and Bifurcaria bifurcata
}

\author{
José M. Lorenzo ${ }^{1, *}$ (D), Rubén Agregán ${ }^{1}$, Paulo E. S. Munekata ${ }^{2}$, Daniel Franco ${ }^{1}$ (D), \\ Javier Carballo ${ }^{3}$, Selin Şahin ${ }^{4}$, Ramón Lacomba ${ }^{5}$ and Francisco J. Barba ${ }^{6, *}$ \\ 1 Centro Tecnológico de la Carne de Galicia, Adva. Galicia n 4, Parque Tecnológico de Galicia, \\ San Cibrao das Viñas, 32900 Ourense, Spain; rubenagregan@ceteca.net (R.A.); danielfranco@ceteca.net (D.F.) \\ 2 Department of Food Engineering, Faculty of Animal Science and Food Engineering, University of São Paulo, \\ 225 Duque de Caxias Norte Ave, Jardim Elite, Pirassununga, São Paulo 13.635-900, Brazil; \\ pmunekata@gmail.com \\ 3 Area de Tecnologia de los Alimentos, Facultad de Ciencias de Ourense, Universidad de Vigo, 32004 Ourense, \\ Spain; carbatec@uvigo.es \\ 4 Department of Chemical Engineering, Engineering Faculty, Istanbul University, Avcilar, 34320 Istanbul, \\ Turkey; selins@istanbul.edu.tr \\ 5 Grupo Alimentario Citrus (GAC), Avda. dels Gremis, Parcela 28 Pol. Ind. Sector 13 del Túria, \\ Riba-roja de Túria, 46394 València, Spain; ramon.lacomba@uv.es \\ 6 Nutrition and Food Science Area, Preventive Medicine and Public Health, Food Science, \\ Toxicology and Forensic Medicine Department, Universitat de València, Avda. Vicent Andrés Estellés, s/n, \\ Burjassot, 46100 València, Spain \\ * Correspondence: jmlorenzo@ceteca.net (J.M.L.); francisco.barba@uv.es (F.J.B.); Tel.: +34-988548277 (J.M.L.); \\ +34-963544972 (F.J.B.); Fax: +34-988548276 (J.M.L.); +34-963544954 (F.J.B.)
}

Received: 8 August 2017; Accepted: 8 November 2017; Published: 15 November 2017

\begin{abstract}
Proximate composition (moisture, protein, lipid and ash content) and nutritional value (fatty acid, amino acid and mineral profile) of three macroalgae (Ascophyllum nodosum, Fucus vesiculosus and Bifurcaria bifurcate) were studied. Chemical composition was significantly $(p<0.001)$ different among the three seaweeds. In this regard, the B. bifurcata presented the highest fat content ( $6.54 \%$ of dry matter); whereas, F. vesiculosus showed the highest protein level (12.99\% dry matter). Regarding fatty acid content, the polyunsaturated fatty acids (PUFAs) were the most abundant followed by saturated fatty acids (SFAs) and monounsaturated fatty acids (MUFAs). On the other hand, the three seaweeds are a rich source of $\mathrm{K}$ (from 3781.35 to $9316.28 \mathrm{mg} / 100 \mathrm{~g}$ ), $\mathrm{Mn}$ (from 8.28 to $1.96 \mathrm{mg} / 100 \mathrm{~g}$ ), $\mathrm{Na}$ (from 1836.82 to $4575.71 \mathrm{mg} / 100 \mathrm{~g}$ ) and Ca (from 984.73 to $1160.27 \mathrm{mg} / 100 \mathrm{~g}$ ). Finally, the most abundant amino acid was glutamic acid (1874.47-1504.53 mg/100 dry matter), followed by aspartic acid (1677.01-800.84 mg/100 g dry matter) and alanine (985.40-655.73 mg/100 g dry matter).
\end{abstract}

Keywords: Ascophyllum nodosum; Fucus vesiculosus; Bifurcaria bifurcate; seaweeds; fatty acid profile; amino acid content; minerals; chemical composition

\section{Introduction}

Seaweeds have been traditionally consumed as food in many cultures, and have been used as condiments, fertilizers, and as source of phycocolloids such as alginate, agar, and carrageenan for industrial applications [1-4]. Seaweeds are traditionally divided into three main groups corresponding to the phylum: green (Chlorophyta), red (Rhodophyta) and brown (Phaeophyta), depending on their chemical composition and nutritional value [5]. 
Seaweeds are consumed in Asia as part of the daily diet. Nowadays, brown algae (66.5\%) are the most consumed species, followed by red (33\%) and green (5\%) algae. Today, Japan, China and South Korea, are the countries with the greatest seaweed consumption [6]. Seaweeds are an excellent nutrient source, containing high amounts of macro- and micronutrients [7], as well as bioactive compounds (e.g., catechins such as gallocatechin, epicatechin and catechingallate, flavonols, and flavonol glycosides) with high antioxidant and health beneficial properties [8-10]. Food, pharmaceutical, and cosmetic industries have shown interest in the recovery of antioxidant compounds (isolated compounds and/or complex extract mixtures) assisted by conventional (solid-liquid or liquid-liquid extraction, Soxhlet, etc.) and innovative processing technologies (high-pressure, supercritical- $\mathrm{CO}_{2}$ (SC- $\mathrm{CO}_{2}$ ), electrotechnologies, microwave- and ultrasound-assisted extraction, among others) $[3,9,11]$.

Several authors [12-15] have reported that the chemical composition of seaweeds varies according to maturity, habitats, environmental conditions, and species. A comprehensive study of nutritional (protein and amino acids, fat and fatty acids, carbohydrates, minerals, and vitamins) and bioactive compounds such as polyphenols, carotenoids, etc., from each seaweed, which can exert some beneficial properties on health, is necessary. There are many brown types of seaweeds found in the Spanish coast and the details of their chemical and nutritional composition are needed in order to fulfil the growing demand for Spanish seaweeds and their derived products. Thus, the aim of the present study was to evaluate the chemical and nutritional properties of three different brown seaweeds A.nodosum, F. vesiculosus and B. bifurcata from the Galician coast.

\section{Results and Discussion}

\subsection{Chemical Composition of Seaweeds}

The proximate composition of the three seaweeds is summarized in Table 1. As can be seen the moisture content showed significant $(p<0.001)$ differences among the three macroalgae, since the lowest value was observed in B. bifurcata (7.95\%).

Table 1. Proximate composition of the three seaweeds studied (mean \pm standard deviation values) $(n=5)$.

\begin{tabular}{cccc}
\hline \multirow{3}{*}{ Parameters } & \multicolumn{3}{c}{ Seaweed } \\
\cline { 2 - 4 } & A. nodosum & F. vesiculosus & B. bifurcata \\
\hline Moisture (g/100 g algae) & $11.08 \pm 0.53^{\mathrm{a}}$ & $11.23 \pm 0.08^{\mathrm{a}}$ & $7.95 \pm 0.06^{\mathrm{b}}$ \\
Protein (g/100 g DW) & $8.70 \pm 0.07^{\mathrm{a}}$ & $12.99 \pm 0.04^{\mathrm{b}}$ & $8.92 \pm 0.09^{\mathrm{c}}$ \\
Lipid (g/100 g DW) & $3.62 \pm 0.17^{\mathrm{a}}$ & $3.75 \pm 0.20^{\mathrm{a}}$ & $6.54 \pm 0.27^{\mathrm{b}}$ \\
Ash (g/100 g DW) & $30.89 \pm 0.06^{\mathrm{a}}$ & $20.71 \pm 0.04^{\mathrm{b}}$ & $31.68 \pm 0.41^{\mathrm{c}}$
\end{tabular}

DW: dry weight of seaweed. ${ }^{\mathrm{a}-\mathrm{c}}$ Means in the same row not followed by a common superscript letter are significantly different $(p<0.05$; Duncan test).

This finding is in close agreement with the data reported by Rodrigues et al. [16], who also noticed that the moisture content of different edible seaweeds species ranged from $8.0 \mathrm{~g} / 100 \mathrm{~g}$ of dry weight (DW) in dried Gracilaria gracilis to $11.8 \mathrm{~g} / 100 \mathrm{~g}$ of DW in dried Osmundea pinnatifida. In addition, Gómez-Ordoñez et al. [14] also reported similar moisture contents (between 6.64\% and 9.86\%) in several edible seaweeds from the northwestern Spanish coast. However, Chan \& Matanjun [17] found lower moisture content (5.32\%) in freeze-dried Gracilaria changii seaweed.

F. vesiculosus specie presented the highest protein content $(12.99 \mathrm{~g} / 100 \mathrm{DW})$, followed by B. bifurcata $(8.92 \mathrm{~g} / 100 \mathrm{DW})$ and the A. nodosum $(8.70 \mathrm{~g} / 100 \mathrm{DW})$. These results are in agreement with the data reported by Fleurence [18], who also noticed low protein content $(<15 \mathrm{~g} / 100 \mathrm{DW})$ in most of the brown seaweeds industrially exploited (F. vesiculosus, A. nodosum, Laminaria digitata and Himanthalia elongata). Similar values were found by Gómez-Ordoñez et al. [14] and Alves et al. [19] in B. bifurcata (10.92 g/100 DW and $8.57 \mathrm{~g} / 100 \mathrm{~g}$ DW, respectively) and by Chan \& Matanjun [17] in G. changii 
(12.57 g/100 DW). However, these values were lower than those obtained by Rodrigues et al. [16] for brown (14.4-16.9 g/100 DW), red (20.2-23.8 g/100 DW) and green (18.8 g/100 DW) seaweed species. In addition, our values were lower than those observed by Fleurence [18] in other seaweed species such as Porphyra tenera (47 g/100 DW) and Palmaria palmata (35 g/100 DW). On the contrary, Sánchez-Machado, López-Cervantes, et al. [20] obtained lower protein content (5.46 g/100 DW) in H. elongata dried seaweed. According to Denis et al. [21], the protein content of seaweed changes during the year, having the maximum content during winter and the beginning of spring, and the minimum content during summer and early autumn periods. In addition, the protein level varied among different algal species, geographic areas, seasons, or environmental conditions [22].

In general, seaweeds exhibit low fat content (bellow 4\%) [23], which varies significantly through the year [24]. Extractable lipid showed significant $(p<0.001)$ differences among seaweeds, since the highest levels were observed in B. bifurcata $(6.54 \% \mathrm{DW})$. Our values were similar to those reported by Peinado et al. [12], who found the contents ranging from 3.95 to $4.64 \%$ DW in F. vesiculosus and by Gómez-Ordoñez et al. [14] and Alves et al. [19], who observed fat levels of 5.67\% DW and 5.81\% DW in B. bifurcata, respectively. On the other hand, ash contents were high and ranged from $20.71 \%$ DW to $31.68 \%$ DW for F. vesiculosus and B. bifurcata, respectively. These findings are in agreement with the data reported by Alves et al. [19] and Gómez-Ordoñez et al. [14] in B. bifurcata (34.31\% DW and $30.15 \%$ DW, respectively) and by Peinado et al. [12] in F. vesiculosus (21-19\% DW). The high ash levels constitute an important characteristic of seaweeds, and are higher than those observed in terrestrial vegetables [7]. It is known that high amounts of ash are linked with high levels of minerals.

\subsection{Mineral Content of Seaweeds}

The mineral content of the three macroalgae is given in Table 2. Among the macrominerals, $\mathrm{K}$ (3781.35-9316.28 mg/100 g DW) was the most abundant element in the three seaweeds studied, followed by $\mathrm{Na}(1836.82-4575.71 \mathrm{mg} / 100 \mathrm{~g}$ DW) and Ca $(984.73-1160.27 \mathrm{mg} / 100 \mathrm{~g}$ DW). A similar trend was reported by other authors $[17,25,26]$, who found that $K$ was the main mineral element followed by $\mathrm{Na}$. On the other hand, B. bifurcata presented a $\mathrm{Na} / \mathrm{K}$ ratio lower than that observed in the other seaweeds ( 0.19 vs. 0.58 vs. 1.21 , for the B. bifurcata, F. vesiculosus and A. nodosum, respectively), which is really interesting from the nutritional viewpoint, because high $\mathrm{Na} / \mathrm{K}$ ratio diets and the hypertension incidence are closely linked [27]. Thus, B. bifurcata could be useful for the regulation of the $\mathrm{Na} / \mathrm{K}$ ratio of diets. In addition, Rodrigues et al. [16] suggested that seaweeds with low ratios of $\mathrm{Na} / \mathrm{K}$ are useful as salt replacers.

The values of manganese in the three macroalgae ranged from $528.04 \mathrm{mg} / 100 \mathrm{~g}$ DW to $867.82 \mathrm{mg} / 100 \mathrm{~g}$ DW, for B. bifurcata and A. nodosum, respectively, differing significantly $(p<0.001)$ among species. These values were higher than those reported by Chan et al. [17] in G. changii (436.13 mg/100 g DW) and lower than the data previously found by Rodrigues et al. [16] in Sargassum muticum (1504 mg/100 g DW) and Codium tomentosum (1046 mg/100 g DW).

On the other hand, Ca contents also showed significant $(p<0.001)$ differences among seaweeds, showing the highest Ca level in F. vesiculosus (1160.27 mg/100 DW). In this regard, Moreiras et al. [28] noticed that Wakame and Sea Spaghetti seaweed species contained approximately eight times more Ca than milk and they could be an excellent source of $\mathrm{Ca}$ for the prevention and treatment of osteoporosis, for growing children, and for pre- and post-menopausal women. Phosphorous, the least abundant macromineral, was also detected in F. vesiculosus and B. bifurcata, ranging from $169.54 \mathrm{mg} / 100 \mathrm{~g}$ DW to $193.57 \mathrm{mg} / 100 \mathrm{~g}$ DW for F. vesiculosus and B. bifurcata, respectively.

A. nodosum and F. vesiculosus also contained iron (ranged from $13.34 \mathrm{mg} / 100 \mathrm{~g}$ DW to $18.99 \mathrm{mg} / 100 \mathrm{~g} \mathrm{DW}$ ) and $\mathrm{Mg}$ (from $1.96 \mathrm{mg} / 100 \mathrm{DW}$ to $8.28 \mathrm{mg} / 100 \mathrm{~g} \mathrm{DW}$ ). Our Fe values were higher than those obtained by Rupérez [7] for Porphyra tenera (10.3 mg/100 g DW), but less than those found by Rao et al. [29] for Porphyra vietnamensis (33 mg/100 g DW). In this regard, F. vesiculosus can be a useful to provide the daily intake of iron and to prevent the anemia caused by iron deficiency [30]. 
Table 2. Mineral profile of the three seaweeds studied (mean \pm standard deviation values) $(n=5)$.

\begin{tabular}{cccc}
\hline Minerals (mg/100 g DW) & \multicolumn{3}{c}{ Seaweed } \\
\cline { 2 - 4 } & A. nodosum & F. vesiculosus & B. bifurcata \\
\hline $\mathrm{Ca}$ & $984.73 \pm 47.26^{\mathrm{a}}$ & $1160.27 \pm 23.10^{\mathrm{b}}$ & $996.42 \pm 12.83^{\mathrm{a}}$ \\
$\mathrm{Fe}$ & $13.34 \pm 0.90^{\mathrm{a}}$ & $18.99 \pm 0.32^{\mathrm{b}}$ & n.q. \\
$\mathrm{K}$ & $3781.35 \pm 13.40^{\mathrm{a}}$ & $3745.05 \pm 36.01^{\mathrm{a}}$ & $9316.28 \pm 101.94^{\mathrm{b}}$ \\
$\mathrm{Mg}$ & $867.82 \pm 12.01^{\mathrm{a}}$ & $732.37 \pm 5.35^{\mathrm{b}}$ & $528.04 \pm 8.25^{\mathrm{c}}$ \\
$\mathrm{Mn}$ & $1.96 \pm 0.69^{\mathrm{a}}$ & $8.28 \pm 1.07^{\mathrm{b}}$ & n.q. \\
$\mathrm{Na}$ & $4575.71 \pm 50.05^{\mathrm{a}}$ & $2187.51 \pm 36.90^{\mathrm{b}}$ & $1836.82 \pm 52.12^{\mathrm{c}}$ \\
$\mathrm{P}$ & n.q. & $193.57 \pm 1.13^{\mathrm{a}}$ & $169.54 \pm 1.41^{\mathrm{b}}$ \\
Zn & n.q. & n.q. & n.q. \\
$\mathrm{Cu}$ & n.q. & n.q. & n.q. \\
Total & $10,224.91 \pm 64.32^{\mathrm{a}}$ & $8045.96 \pm 94.44^{\mathrm{b}}$ & $12,848.97 \pm 142.01^{\mathrm{c}}$
\end{tabular}

n.q. = not quantified. DW: dry weight of seaweed. ${ }^{\text {a-c }}$ Means in the same row not followed by a common superscript letter are significantly different $(p<0.05$; Duncan test).

\subsection{Amino Acid Content of Seaweeds}

The amino acid (AA) composition of the three seaweeds evaluated is summarized in Table 3. The total AA contents were 7.48, 11.90 and $7.32 \mathrm{~g} / 100 \mathrm{~g}$ DW $(p<0.001)$, for A. nodosum, F. vesiculosus, and B. bifurcata, respectively; and these values were comparable to corresponding crude protein levels (Table 1), thus showing that the amount of non-protein nitrogenous materials in these seaweeds was negligible.

Table 3. Amino acid profile of the three seaweeds studied (mean \pm standard deviation values) $(n=5)$.

\begin{tabular}{cccc}
\hline \multirow{2}{*}{ Amino Acids (mg/100 g DW) } & \multicolumn{3}{c}{ Seaweed } \\
\cline { 2 - 4 } & A. nodosum & F. vesiculosus & B. bifurcata \\
\hline \multicolumn{4}{c}{ Essential amino acids } \\
\hline Threonine & $363.22 \pm 17.12^{\mathrm{a}}$ & $613.08 \pm 33.62^{\mathrm{b}}$ & $360.27 \pm 38.25^{\mathrm{a}}$ \\
Valine & $353.89 \pm 32.95^{\mathrm{a}}$ & $582.70 \pm 36.73^{\mathrm{b}}$ & $372.82 \pm 49.05^{\mathrm{a}}$ \\
Methionine & $147.59 \pm 18.71^{\mathrm{a}}$ & $218.21 \pm 20.20^{\mathrm{b}}$ & $178.41 \pm 18.08^{\mathrm{a}}$ \\
Isoleucine & $295.26 \pm 25.73^{\mathrm{a}}$ & $507.82 \pm 32.42^{\mathrm{b}}$ & $299.73 \pm 37.74^{\mathrm{a}}$ \\
Leucine & $537.37 \pm 38.87^{\mathrm{a}}$ & $862.14 \pm 57.02^{\mathrm{b}}$ & $524.59 \pm 61.38^{\mathrm{a}}$ \\
Phenylalanine & $340.13 \pm 17.74^{\mathrm{a}}$ & $541.53 \pm 25.72^{\mathrm{b}}$ & $330.05 \pm 32.32^{\mathrm{a}}$ \\
Lysine & $431.72 \pm 38.40^{\mathrm{a}}$ & $800.28 \pm 74.20^{\mathrm{b}}$ & $393.06 \pm 56.57^{\mathrm{a}}$ \\
Histidine & $126.46 \pm 10.65^{\mathrm{a}}$ & $194.59 \pm 8.73^{\mathrm{b}}$ & $138.76 \pm 12.70^{\mathrm{a}}$ \\
Arginine & $316.79 \pm 14.05^{\mathrm{a}}$ & $557.87 \pm 38.44^{\mathrm{b}}$ & $330.11 \pm 42.41^{\mathrm{a}}$ \\
Total EAA & $2912.42 \pm 204.93^{\mathrm{a}}$ & $4878.22 \pm 304.12^{\mathrm{b}}$ & $2927.79 \pm 346.84^{\mathrm{a}}$ \\
\hline & Non-essential amino acids & \\
\hline Tyrosine & $162.85 \pm 24.50^{\mathrm{a}}$ & $327.01 \pm 30.59^{\mathrm{b}}$ & $175.00 \pm 30.90^{\mathrm{a}}$ \\
Asparagine & $846.64 \pm 38.87^{\mathrm{a}}$ & $1677.01 \pm 156.39^{\mathrm{b}}$ & $800.84 \pm 105.55^{\mathrm{a}}$ \\
Serine & $378.62 \pm 13.57^{\mathrm{ab}}$ & $630.54 \pm 47.00^{\mathrm{a}}$ & $357.10 \pm 36.87^{\mathrm{b}}$ \\
Glutamic acid & $1714.55 \pm 133.17^{\mathrm{a}}$ & $1974.47 \pm 150.67^{\mathrm{b}}$ & $1504.53 \pm 178.74^{\mathrm{a}}$ \\
Glycine & $417.70 \pm 12.89^{\mathrm{a}}$ & $651.24 \pm 30.84^{\mathrm{b}}$ & $390.14 \pm 29.42^{\mathrm{a}}$ \\
Alanine & $655.73 \pm 34.75^{\mathrm{a}}$ & $985.40 \pm 69.50^{\mathrm{b}}$ & $846.65 \pm 82.87^{\mathrm{c}}$ \\
Proline & $399.24 \pm 11.70^{\mathrm{a}}$ & $575.19 \pm 39.15^{\mathrm{b}}$ & $318.40 \pm 40.96^{\mathrm{c}}$ \\
Cysteine & $0.00 \pm 0.00^{\mathrm{a}}$ & $205.23 \pm 25.43^{\mathrm{b}}$ & $0.00 \pm 0.00^{\mathrm{a}}$ \\
Total NEAA & $4575.33 \pm 198.91^{\mathrm{a}}$ & $7026.10 \pm 512.60^{\mathrm{b}}$ & $4392.67 \pm 502.38^{\mathrm{a}}$ \\
Total AA & $7487.76 \pm 400.31^{\mathrm{a}}$ & $11,904.32 \pm 816.67^{\mathrm{b}}$ & $7320.46 \pm 848.14^{\mathrm{a}}$ \\
\hline Relative Amount EAA (\%) & $38.87 \pm 0.71^{\mathrm{a}}$ & $40.99 \pm 0.26^{\mathrm{b}}$ & $39.99 \pm 0.31^{\mathrm{c}}$ \\
\hline DW: & & & \\
\hline
\end{tabular}

DW: dry weight of seaweed. ${ }^{\text {a-c }}$ Means in the same row not followed by a common superscript letter are significantly different $(p<0.05$; Duncan test). EAA: Essential Amino acids. 
The three seaweeds studied contained all the essential amino acids (EAAs) (excluding cysteine in the A. nodosum and B. bifurcata). The EAAs content ranged from $3075.28 \mathrm{mg} / 100 \mathrm{~g}$ DW to $5205.23 \mathrm{mg} / 100 \mathrm{~g}$ DW for the A. nodosum and F. vesiculosus, respectively, showing significant differences among species. The EAA/total AA ratio suggests that more than $40 \%$ of the AAs were EAAs. This ratio was lower than the data reported by Chan et al. [17], who observed the ratios (above $55 \%$ ) in G. changii, but comparable to Porphyra umbilicalis (36.87\%), Undaria pinnatifida (42.72\%) and H. elongata (40.82\%) reported by Cofrades et al. [13]. In the essential fraction, leucine was the most abundant, ranging from $524.59 \mathrm{mg} / 100 \mathrm{~g}$ DW to $862.14 \mathrm{mg} / 100 \mathrm{~g}$ DW for B. bifurcata and F. vesiculosus, respectively, followed by lysine (393.06-800.28 mg/100 g DW), threonine (360.27-613.08 mg/100 g $\mathrm{DW})$ and valine (353.89-582.70 mg/100 g DW). These findings were not in agreement with those reported by Chan et al. [17], who observed that arginine was found to be the highest EAA in G. changii, representing $18.69 \%$ of the total AAs. On the other hand, glutamic and aspartic acids were the major amino acids found in the non-essential fraction and theses two AAs accounted between $30.67 \%$ and $34.20 \%$ of the total AAs, for the FV and AN species, respectively. The sum of aspartic and glutamic acids was higher than data reported by other authors $[13,17]$ who found values below $25 \%$ in different seaweed species. According to Saini et al. [31], the special flavor and taste of seaweeds in linked to the glutamic and aspartic acids contents. The next highest NEEA were alanine $>$ glycine $>$ serine $>$ proline. Finally, the protein quality of FV seaweed is better than those the other ones, because cysteine is lacking in the AN and BB species.

The nutritional quality of the three seaweeds studied is shown in Table 4 . The chemical score (CS) for each of the essential amino acids with respect to the pattern protein, as proposed by Food and Agriculture Organization of the United Nations (FAO)/World Health Organization (WHO)/United Nations (UNU) [32] for humans (children > 1-year old and adults) was calculated.

Table 4. Nutritional quality of protein for the three seaweeds studied.

\begin{tabular}{|c|c|c|c|c|c|}
\hline \multirow{2}{*}{ Amino Acid } & \multirow{2}{*}{$\begin{array}{l}\text { IOM/FNB } \\
(2002)\end{array}$} & \multirow{2}{*}{$\begin{array}{c}\text { FAO/WHO/UNU } \\
(2007)\end{array}$} & \multicolumn{3}{|c|}{ Seaweeds } \\
\hline & & & A. nodosum (CS) & F. vesiculosus (CS) & B. bifurcata (CS) \\
\hline Histidine & 1.8 & 1.5 & 96.8 & 99.8 & 103.7 \\
\hline Isoleucine & 2.5 & 3.0 & 113.1 & 130.3 & 112.0 \\
\hline Leucine & 5.5 & 5.9 & 104.7 & 112.5 & 99.7 \\
\hline Lysine & 5.1 & 4.5 & 110.3 & 136.9 & 97.9 \\
\hline Met + Cys & 2.5 & 1.6 & 105.9 & 203.8 & 125.0 \\
\hline Phe + Tyr & 4.7 & 3.8 & 152.1 & 176.0 & 149.0 \\
\hline Threonine & 2.7 & 2.3 & 181.5 & 125.0 & 175.6 \\
\hline Valine & 3.2 & 3.9 & 104.3 & 115.0 & 107.2 \\
\hline IAEE & & & 118.4 & 133.9 & 118.8 \\
\hline
\end{tabular}

Seaweeds: A. nodosum = Ascophyllum nodosum; F. vesiculosus = Fucus vesiculosus; and B. bifurcate = Bifurcaria bifurcata . Pattern proteins are expressed in (g/100 g protein). Values of CS and IEAA (Index Essential Amino Acids) are referred only respect to $\mathrm{FAO} / \mathrm{WHO} / \mathrm{UNU}$ (2007) protein pattern.

The profile of the Institute of Medicine, Food and Nutrition (FNB) [33] is also shown for comparative purposes. The analysis of the CS allows the order of the restrictive amino acids to be determined. Concentration of all the essential amino acids were above the FAO/WHO/UNU [32] except for histidine in the A. nodosum and F. vesiculosus and leucine and lysine in B. bifurcata. Thus, histidine was the most limiting AA found in A. nodosum and F. vesiculosus and lysine seemed to be the limiting AA in B. bifurcata. This is in agreement with the data found by Cofrades et al. [13], who found that the most limiting AA in the brown seaweeds was lysine. However, Chan et al. [17] observed that methionine was the most limiting AA found in G. changii.

\subsection{Fatty Acid Profile of Seaweeds}

Table 5 shows the fatty acid profile of the three seaweeds studied. The polyunsaturated fatty acids (PUFAs) were the most abundant, ranging from $43.47 \%$ to $48.19 \%$ for the A. nodosum 
and $F$. vesiculosus, respectively. This result is in agreement with the data previously reported by other authors $[13,17,19]$, who found that PUFAs were the main fatty acids in seaweeds. However, Pen et al. [34] and Maehre et al. [15] observed higher saturated fatty acid (SFA) content in different seaweed species.

In the present study, the percentage of fatty acid differed significantly $(p<0.001)$ among seaweeds. In this regard, the highest oleic acid (C18:1n-9) content (27.83-19.94\%) was found in A. nodosum and F. vesiculosus, whereas B. bifurcata presented the highest arachidonic acid (C20:4n-6) level (15.24\%). A similar trend was reported by Peinado et al. [12] and Ortiz et al. [35], who observed that oleic acid was the main fatty acid in seaweed samples. On the contrary, Chan et al. [17] and Alves et al. [19] reported that docosahexaenoic acid (C22:6n-3; DHA) and palmitic acid (C16:0) were the most abundant fatty acids in G. changgi and B. bifurcata, respectively. These differences on the fatty acid profile could be due to differences among species, as well as other abiotic factors such as light, salinity, and nutrients [36].

Table 5. Fatty acid profile of the three seaweeds studied (mean \pm standard deviation values) $(n=5)$.

\begin{tabular}{|c|c|c|c|}
\hline \multirow{2}{*}{ Fatty Acids } & \multicolumn{3}{|c|}{ Seaweed } \\
\hline & A. nodosum & F. vesiculosus & B. bifurcata \\
\hline C14:0 & $9.40 \pm 0.11^{a}$ & $11.38 \pm 0.11^{b}$ & $4.52 \pm 0.46^{c}$ \\
\hline $\mathrm{C} 14: 1 n-5$ & $0.28 \pm 0.00^{\mathrm{a}}$ & $0.10 \pm 0.00^{\mathrm{b}}$ & $0.00 \pm 0.00^{c}$ \\
\hline C15:0 & $0.30 \pm 0.00^{\mathrm{a}}$ & $0.37 \pm 0.00^{\mathrm{b}}$ & $0.17 \pm 0.01^{c}$ \\
\hline $\mathrm{C} 16: 0$ & $13.42 \pm 0.46^{\mathrm{a}}$ & $14.66 \pm 0.36^{b}$ & $17.35 \pm 0.43^{c}$ \\
\hline $\mathrm{C} 16: 1 n-7$ & $2.24 \pm 0.01^{\mathrm{a}}$ & $1.18 \pm 0.02^{b}$ & $2.51 \pm 0.16^{\mathrm{c}}$ \\
\hline C17:0 & $0.41 \pm 0.14^{\mathrm{a}}$ & $0.82 \pm 0.15^{b}$ & $0.54 \pm 0.02^{a}$ \\
\hline $\mathrm{C} 17: 1 n-7$ & $0.29 \pm 0.00^{\mathrm{a}}$ & $0.20 \pm 0.00^{\mathrm{b}}$ & $1.87 \pm 0.07^{c}$ \\
\hline C18:0 & $0.76 \pm 0.01^{\mathrm{a}}$ & $1.06 \pm 0.08^{b}$ & $1.75 \pm 0.13^{c}$ \\
\hline $\mathrm{C} 18: 1 n-11$ trans & $0.00 \pm 0.00^{\mathrm{a}}$ & $0.00 \pm 0.00^{\mathrm{a}}$ & $3.57 \pm 0.13^{b}$ \\
\hline C18:1n-9 cis & $27.83 \pm 0.26^{\mathrm{a}}$ & $19.94 \pm 0.31^{b}$ & $12.61 \pm 0.35^{c}$ \\
\hline $\mathrm{C} 18: 1 n-7$ cis & $0.45 \pm 0.05^{\mathrm{a}}$ & $0.39 \pm 0.04^{\mathrm{a}}$ & $0.52 \pm 0.03^{b}$ \\
\hline $\mathrm{C} 18: 2 n-6$ trans & $0.11 \pm 0.00^{\mathrm{a}}$ & $0.06 \pm 0.00^{\mathrm{a}}$ & $5.68 \pm 0.21^{b}$ \\
\hline $\mathrm{C} 18: 2 n-6$ cis & $7.47 \pm 0.12^{\mathrm{a}}$ & $6.43 \pm 0.08^{b}$ & $1.92 \pm 0.06^{c}$ \\
\hline C20:0 & $0.22 \pm 0.01^{\mathrm{a}}$ & $0.39 \pm 0.01^{b}$ & $1.89 \pm 0.18^{c}$ \\
\hline $\mathrm{C} 18: 3 n-6$ & $0.54 \pm 0.01^{\mathrm{a}}$ & $0.56 \pm 0.01^{\mathrm{a}}$ & $0.42 \pm 0.05^{b}$ \\
\hline C20:1n-9 & $0.07 \pm 0.01^{\mathrm{a}}$ & $0.53 \pm 0.01^{b}$ & $4.18 \pm 0.12^{c}$ \\
\hline $\mathrm{C} 18: 3 n-3$ & $4.45 \pm 0.03^{\mathrm{a}}$ & $7.59 \pm 0.11^{b}$ & $3.97 \pm 0.09^{c}$ \\
\hline C18:2n-7 (CLA) & $0.00 \pm 0.00^{\mathrm{a}}$ & $0.00 \pm 0.00^{\mathrm{a}}$ & $0.87 \pm 0.10^{b}$ \\
\hline C21:0 & $0.00 \pm 0.00^{\mathrm{a}}$ & $0.00 \pm 0.00^{\mathrm{a}}$ & $0.71 \pm 0.07^{b}$ \\
\hline$C 20: 2 n-6$ & $5.05 \pm 0.02^{\mathrm{a}}$ & $6.46 \pm 0.09^{b}$ & $1.44 \pm 0.01^{\mathrm{c}}$ \\
\hline C22:0 & $0.22 \pm 0.00^{\mathrm{a}}$ & $0.22 \pm 0.00^{\mathrm{a}}$ & $0.34 \pm 0.02^{b}$ \\
\hline$C 20: 3 n-6$ & $0.74 \pm 0.04^{\mathrm{a}}$ & $0.69 \pm 0.02^{b}$ & $0.42 \pm 0.04^{\mathrm{c}}$ \\
\hline $\mathrm{C} 22: 1 n-9$ & $0.00 \pm 0.00^{\mathrm{a}}$ & $0.00 \pm 0.00^{\mathrm{a}}$ & $0.73 \pm 0.04^{b}$ \\
\hline C20:3n-3 & $0.33 \pm 0.01^{\mathrm{a}}$ & $0.21 \pm 0.00^{b}$ & $0.00 \pm 0.00^{c}$ \\
\hline C20:4n-6 & $17.25 \pm 0.26^{a}$ & $15.86 \pm 0.24^{b}$ & $15.24 \pm 0.37^{c}$ \\
\hline $\mathrm{C} 22: 2 n-6$ & $0.29 \pm 0.01^{\mathrm{a}}$ & $0.39 \pm 0.01^{b}$ & $1.76 \pm 0.09^{c}$ \\
\hline $\mathrm{C} 20: 5 n-3$ & $7.24 \pm 0.08^{a}$ & $9.94 \pm 0.14^{b}$ & $4.09 \pm 0.08^{c}$ \\
\hline C24:0 & $0.41 \pm 0.00^{\mathrm{a}}$ & $0.36 \pm 0.01^{b}$ & $0.34 \pm 0.03^{b}$ \\
\hline C24:1n-9 & $0.00 \pm 0.00^{\mathrm{a}}$ & $0.00 \pm 0.00^{\mathrm{a}}$ & $0.53 \pm 0.06^{b}$ \\
\hline C22:6n-3 & $0.00 \pm 0.00^{\mathrm{a}}$ & $0.00 \pm 0.00^{\mathrm{a}}$ & $11.10 \pm 1.13^{b}$ \\
\hline SFA & $25.14 \pm 0.49^{\mathrm{a}}$ & $29.26 \pm 0.34^{b}$ & $27.62 \pm 0.77^{c}$ \\
\hline MUFA & $31.15 \pm 0.23^{a}$ & $22.33 \pm 0.33^{b}$ & $26.51 \pm 0.48^{c}$ \\
\hline PUFA & $43.47 \pm 0.54^{\mathrm{a}}$ & $48.19 \pm 0.62^{b}$ & $46.91 \pm 1.37^{b}$ \\
\hline$n-3$ & $12.02 \pm 0.11^{\mathrm{a}}$ & $17.74 \pm 0.25^{b}$ & $19.16 \pm 1.03^{c}$ \\
\hline$n-6$ & $31.45 \pm 0.42^{\mathrm{a}}$ & $30.44 \pm 0.38^{b}$ & $26.87 \pm 0.48^{c}$ \\
\hline$n-6 / n-3$ & $2.62 \pm 0.01^{\mathrm{a}}$ & $1.72 \pm 0.01^{b}$ & $1.41 \pm 0.07^{c}$ \\
\hline
\end{tabular}

Results expressed as percentage of total fatty acid analyzed. ${ }^{a-c}$ means in the same row not followed by a common superscript letter are significantly different $(p<0.05$; Duncan test). Saturated fatty acids: SFA. Monounsaturated fatty acids: MUFA. Polyunsaturated fatty acids: PUFA. 
Eicosapentaenoic acid (EPA) (C20:5n-3) represented from 4.09 to $9.94 \%$ of the total fatty acids, whereas docosahexaenoic acid (DHA) was only detected in B. bifurcata $(11.10 \%$ of the total fatty acids). Other studies reported similar EPA percentages in brown algae $[12,19,20]$. In another work, Maehre et al. [15] found that none of the algae contained DHA, whereas the EPA content varied considerably among species.

On the other hand, Western country diets are deficient in $n-3$ fatty acids due to the low seafood consumption versus the high intake of $n-6$ fatty acid from vegetable oil. In this regard, the World Health Organization (WHO) [30] recommended a $n-6 / n-3$ ratio below 10. In our study, we observed $n-6 / n-3$ ratio ranging from 2.62 to 1.41 , placing the three macroalgae studied according $\mathrm{WHO}$ recommendations. This outcome is in agreement with those reported by other authors $[17,19,35]$ who found $n-6 / n-3$ ratios between 4.1 and 0.02 .

\section{Material and Methods}

\subsection{Algal Material}

The brown seaweeds, A. nodosum, F. vesiculosus and B. bifurcata used in the present study, were kindly supplied by Portomuiños Company (A Coruña, Spain). They were collected from August to September 2015, in the Atlantic Ocean, in the area of Camariñas (A Coruña, Spain). The samples were grinded to obtain powder with a particle size lower than $0.8 \mathrm{~mm}$, using a conventional mincer. Then, the seaweeds were passed through a $0.8 \mathrm{~mm}$ mesh sieve and stored under vacuum in plastics bags at $-20{ }^{\circ} \mathrm{C}$ until analysis.

\subsection{Chemical Composition}

Moisture, protein, and ash were determined following the ISO recommendations (ISO 1442:1997 [37], ISO 937:1978 [38], and ISO 936:1998 [39], respectively). Moisture content was determined by measuring sample $(3 \mathrm{~g})$ weight loss at $105{ }^{\circ} \mathrm{C}$ in an oven (Memmert UFP 600, Schwabach, Germany), until constant weight. Kjeldahl total nitrogen method was used to determine protein percentage (total nitrogen content was multiplied $\times 6.25$ ). Five hundred milligrams of seaweed were subjected to reaction with $\mathrm{H}_{2} \mathrm{SO}_{4}\left(\mathrm{CuSO}_{4} \cdot 5 \mathrm{H}_{2} \mathrm{O}\right.$ was employed as a catalyst) in a digester (Gerhardt Kjeldatherm KB, Bonn, Germany), then the organic nitrogen was transformed into $\left(\mathrm{NH}_{4}\right)_{2} \mathrm{SO}_{4}$, and distilled in alkali condition (Gerhardt Vapodest 50 carroused, Bonn, Germany). Ash content was assessed by determining seaweed ( $3 \mathrm{~g}$ ) weight loss in a muffle furnace (Carbolite RWF 1200, Hope Valley, UK) at $600{ }^{\circ} \mathrm{C}$ until constant weight. Lipids were determined using the method proposed by Ortiz et al. [35] with some modifications. Lipids from each seaweed $(20 \mathrm{~g})$ were extracted with $300 \mathrm{~mL}$ of $\mathrm{CHCl}_{3} / \mathrm{CH}_{3} \mathrm{OH} / \mathrm{H}_{2} \mathrm{O}$ (1:2:0.8), overnight under dark condition. Then, $79 \mathrm{~mL}$ of chloroform and $79 \mathrm{~mL}$ of water were added to each sample, obtaining a final solvent ratio of $\mathrm{CHCl}_{3} / \mathrm{CH}_{3} \mathrm{OH} / \mathrm{H}_{2} \mathrm{O}$ of 1:1:0.9 by volume. $\mathrm{NaCl}(5 \%)$ was added and then, samples were centrifuged at $4000 \mathrm{rpm}$ during $10 \mathrm{~min}$. Chloroform phase was concentrated under vacuum condition in order to recover the lipids, which were gravimetrically measured.

\subsection{Amino Acid Content}

Amino acids were extracted following the method proposed by Lorenzo et al. [40]. Amino acids were derived using 6-aminoquinolyl- $N$-hydroxysuccinimidyl carbamate (Waters AccQ-Fluor reagent kit) and determined by RP-HPLC (Waters 2695 Separations Module + Waters 2475 Multi Fluorescence Detector + Waters AccQ-Tag amino acids analysis column). The amino acids content was expressed in $\mathrm{mg} / 100 \mathrm{~g}$ of dry matter. 


\subsection{Protein Quality: Chemical Score of Amino Acids}

The chemical score (CS) of the essential amino acids was determined using a protein pattern recommended by $\mathrm{FAO} / \mathrm{WHO} / \mathrm{UNU}$ [32] as reference protein applying the next equation (Equation (1)):

$$
C S=\frac{g \text { EAA in tested protein }}{g \text { EAA in pattern protein }} \times 100
$$

The essential amino acids index (EAA) value was also assessed according to the Equation (2) [40]:

$$
E A A=100 \times \sqrt[n]{\frac{a}{a_{p}} \times \frac{b}{b_{p}} \times \frac{c}{c_{p}} \times \ldots \ldots \frac{j}{j_{p}}}
$$

where:

$a, b, c, \ldots, j=$ content of Phe, Tyr, Val, Met, Thr, Lys, His, Ile and Leu in seaweeds.

$a_{p}, b_{p}, c_{p}, \ldots, j_{p}=$ content of Phe, Tyr, Val, Met, Thr, Lys, His, Ile and Leu in protein standard [32].

$n=$ number of amino acids used.

\subsection{Fatty Acid Profile}

The lipids extracted $(50 \mathrm{mg}$ ) were used to determine fatty acid profile. Total fatty acids were transesterified using the method previously by Domínguez et al. [41]. A GC equipment (GC-Agilent $6890 \mathrm{~N}$; Agilent Technologies Spain, S.L., Madrid, Spain) with a flame ionization detector was used for the separation and quantification of the fatty acids methyl esters (FAMEs) using the chromatographic conditions proposed by Domínguez et al. [41]. Individual FAMEs were identified by comparing their retention times with those of authentic standards (Supelco 37 component FAME Mix, Sigma-Aldrich, Barcelona, Spain). C18:1n-7 cis (Supelco cis-11-Vaccenic methyl ester), C18:1n-11 trans (trans-11-vaccenic methyl ester) and C18:2n-7 (CLA) (Matreya LLC Methyl 9(z), 11 (E)-octadecadienoate) were not included in the commercial mix. In addition, nonadecanoic acid (C19:0) was used as internal standard, which was added to the samples prior to methylation. Data were expressed in $\mathrm{g} / 100 \mathrm{~g}$ of FAME.

\subsection{Mineral Profile}

The ash samples obtained by ISO recommended standard method [39] were dissolved in $10 \mathrm{~mL}$ of $1 \mathrm{M} \mathrm{HNO}_{3}$. Mineral $(\mathrm{Ca}, \mathrm{Fe}, \mathrm{K}, \mathrm{Mg}, \mathrm{Mn}, \mathrm{Na}, \mathrm{P}, \mathrm{Zn}$ and $\mathrm{Cu}$ ) was determined by inductively coupled plasma-optical emission spectroscopy (ICP-OES), using a Thermo-Fisher ICAP 6000 plasma emission spectrometer (Thermo-Fisher, Cambridge, UK), following the method proposed by Lorenzo et al. [42]. All determinations were made in triplicate.

\subsection{Statistical Analysis}

The differences in proximate composition, amino acid, fatty acid and mineral profiles among the three seaweeds studied were examined using an ANOVA test. Least-squares means were compared among seaweeds using the Duncan's post hoc test (significance level $p<0.05$ ). The values were given in terms of mean values \pm standard deviations. All statistical analysis were performed using IBM SPSS Statistics ${ }^{\circledR} 21$ software (IBM Corporation, Armonk, NY, USA).

\section{Conclusions}

Among the three seaweeds studied (A. nodosum, F. vesiculosus, and B. bifurcata), B. bifurcata had the highest level of lipid and ash. It should also be noted that although B. bifurcata had the highest total mineral and $\mathrm{K}$ contents, F. vesiculosus presented the highest $\mathrm{Ca}, \mathrm{Fe}, \mathrm{Mn}$, and $\mathrm{P}$ contents, while $\mathrm{A}$. nodosum presented the highest $\mathrm{Mg}$, and $\mathrm{Na}$ contents. This fact is of a great importance, 
especially when seaweeds are used to extract targeted minerals to be used in diets. F. vesiculosus had the highest protein content. The three seaweeds studied contained all the essential amino acids (excluding Cys in the A. nodosum and B. bifurcata). Glu and Asp acids were the predominant amino acids found in the non-essential fraction and theses two amino acids accounted between $30.67 \%$ and $34.20 \%$ of the total amino acids, for the F. vesiculosus and A. nodosum, respectively. Concentration of all the essential amino acids were above the chemical score established by FAO/WHO/UNU except for His in the A.nodosum and F. vesiculosus seaweeds and Leu and Lys in the B. bifurcata. Regarding fatty acids, polyunsaturated fatty acid (PUFA) were the predominant fatty acids in the three seaweeds evaluated, ranging from $43.47 \%$ to $48.19 \%$ for $A$. nodosum and F. vesiculosus, respectively. The highest oleic acid content (27.83-19.94\%) was found in A. nodosum and F. vesiculosus, whereas B. bifurcata presented the highest arachidonic acid level (15.24\%). Moreover, the $n-6 / n-3$ ratio ranged from 2.62 to 1.41 , placing the three macroalgae studied according to WHO recommendations $(n-6 / n-3$ ratio $<10)$.

Acknowledgments: The authors thank INIA (Instituto Nacional de Investigaciones Agrarias y Alimentarias, Spain) for granting Ruben Agregán with a predoctoral scholarship (CPR2014-0128).

Author Contributions: José M. Lorenzo, Rubén Agregán, Paulo E. S. Munekata, Daniel Franco and Javier Carballo conceived, designed and performed the experiments; Selin Şahin, Ramón Lacomba and Francisco J. Barba supervised the study, wrote and reviewed the manuscript. All authors have read and approved the final manuscript.

Conflicts of Interest: The authors declare no conflict of interest, and the founding sponsors had no role in the design of the study; in the collection, analyses, or interpretation of data; in the writing of the manuscript, and in the decision to publish the results.

\section{References}

1. Peña-Rodríguez, A.; Mawhinney, T.P.; Ricque-Marie, D.; Cruz-Suárez, L.E. Chemical composition of cultivated seaweed Ulva clathrata (Roth) C. Agardh. Food Chem. 2011, 129, 491-498. [CrossRef]

2. Yaich, H.; Garna, H.; Besbes, S.; Paquot, M.; Blecker, C.; Attia, H. Chemical composition and functional properties of Ulva lactuca seaweed collected in Tunisia. Food Chem. 2011, 128, 895-901. [CrossRef]

3. Roohinejad, S.; Koubaa, M.; Barba, F.J.; Saljoughian, S.; Amid, M.; Greiner, R. Application of seaweeds to develop new food products with enhanced shelf-life, quality and health-related beneficial properties. Food Res. Int. 2016, 99, 1066-1083. [CrossRef] [PubMed]

4. Barba, F.J. Microalgae and seaweeds for food applications: Challenges and perspectives. Food Res. Int. 2016, 99, 969-970. [CrossRef] [PubMed]

5. Gupta, S.; Abu-Ghannam, N. Recent developments in the application of seaweeds or seaweed extracts as a means for enhancing the safety and quality attributes of foods. Innov. Food Sci. Emerg. Technol. 2011, 12, 600-609. [CrossRef]

6. Dawes, C.J. Marine Botany; Dawes, C.J., Ed.; John Wiley \& Sons, Inc.: New York, NY, USA, 1998.

7. Rupérez, P. Mineral content of edible marine seaweeds. Food Chem. 2002, 79, 23-26. [CrossRef]

8. Agregán, R.; Munekata, P.E.S.; Franco, D.; Dominguez, R.; Carballo, J.; Lorenzo, J.M. Phenolic compounds from three brown seaweed species using LC-DAD-ESI-MS/MS. Food Res. Int. 2016, 99, 979-985. [CrossRef] [PubMed]

9. Poojary, M.M.; Barba, F.J.; Aliakbarian, B.; Donsì, F.; Pataro, G.; Dias, D.A.; Juliano, P. Innovative alternative technologies to extract carotenoids from microalgae and seaweeds. Mar. Drugs 2016, 14, 214. [CrossRef] [PubMed]

10. Roselló-Soto, E.; Galanakis, C.M.; Brnčić, M.; Orlien, V.; Trujillo, F.J.; Mawson, R.; Knoerzer, K.; Tiwari, B.K.; Barba, F.J. Clean recovery of antioxidant compounds from plant foods, by-products and algae assisted by ultrasound processing. Modeling approaches to optimize processing conditions. Trends Food Sci. Technol. 2015, 42, 134-149. [CrossRef]

11. Zhu, Z.; Wu, Q.; Di, X.; Li, S.; Barba, F.J.; Koubaa, M.; Roohinejad, S.; Xiong, X.; He, J. Multistage recovery process of seaweed pigments: Investigation of ultrasound assisted extraction and ultra-filtration performances. Food Bioprod. Process. 2017, 104, 40-47. [CrossRef]

12. Peinado, I.; Girón, J.; Koutsidis, G.; Ames, J.M. Chemical composition, antioxidant activity and sensory evaluation of five different species of brown edible seaweeds. Food Res. Int. 2014, 66, 36-44. [CrossRef] 
13. Cofrades, S.; López-Lopez, I.; Bravo, L.; Ruiz-Capillas, C.; Bastida, S.; Larrea, M.T.; Jiménez-Colmenero, F. Nutritional and antioxidant properties of different brown and red Spanish edible seaweeds. Food Sci. Technol. Int. 2010, 16, 361-370. [CrossRef] [PubMed]

14. Gómez-Ordóñez, E.; Jiménez-Escrig, A.; Rupérez, P. Dietary fibre and physicochemical properties of several edible seaweeds from the northwestern Spanish coast. Food Res. Int. 2010, 43, 2289-2294. [CrossRef]

15. Mæhre, H.K.; Malde, M.K.; Eilertsen, K.-E.; Elvevoll, E.O. Characterization of protein, lipid and mineral contents in common Norwegian seaweeds and evaluation of their potential as food and feed. J. Sci. Food Agric. 2014, 94, 3281-3290. [CrossRef] [PubMed]

16. Rodrigues, D.; Freitas, A.C.; Pereira, L.; Rocha-Santos, T.A.P.; Vasconcelos, M.W.; Roriz, M.; Rodríguez-Alcalá, L.M.; Gomes, A.M.P.; Duarte, A.C. Chemical composition of red, brown and green macroalgae from Buarcos bay in Central West Coast of Portugal. Food Chem. 2015, 183, 197-207. [CrossRef] [PubMed]

17. Chan, P.T.; Matanjun, P. Chemical composition and physicochemical properties of tropical red seaweed, Gracilaria changii. Food Chem. 2017, 221, 302-310. [CrossRef] [PubMed]

18. Fleurence, J. Seaweed proteins: Biochemical, nutritional aspects and potential uses. Trends Food Sci. Technol. 1999, 10, 25-28. [CrossRef]

19. Alves, C.; Pinteus, S.; Simões, T.; Horta, A.; Silva, J.; Tecelão, C.; Pedrosa, R. Bifurcaria bifurcata: A key macro-alga as a source of bioactive compounds and functional ingredients. Int. J. Food Sci. Technol. 2016, 51, 1638-1646. [CrossRef]

20. Sánchez-Machado, D.I.; López-Cervantes, J.; López-Hernández, J.; Paseiro-Losada, P.; Simal-Lozano, J. Determination of the uronic acid composition of seaweed dietary fibre by HPLC. Biomed. Chromatogr. 2004, 18, 90-97. [CrossRef] [PubMed]

21. Denis, C.; Morançais, M.; Li, M.; Deniaud, E.; Gaudin, P.; Wielgosz-Collin, G.; Barnathan, G.; Jaouen, P.; Fleurence, J. Study of the chemical composition of edible red macroalgae Grateloupia turuturu from Brittany (France). Food Chem. 2010, 119, 913-917. [CrossRef]

22. Ito, K.; Hori, K. Seaweed: Chemical composition and potential food uses. Food Rev. Int. 1989, 5, $101-144$. [CrossRef]

23. Herbreteau, F.; Coiffard, L.J.M.; Derrien, A.; De Roeck-Holtzhauer, Y. The fatty acid composition of five species of macroalgae. Bot. Mar. 1997, 40, 25-27. [CrossRef]

24. Manivannan, K.; Thirumaran, G.; Devi, G.K.; Hemalatha, A.; Anantharaman, P. Biochemical composition of seaweeds from Mandapam coastal regions along Southeast Coast of India. Am. J. Bot. 2008, 1, 32-37.

25. Kumar, M.; Kumari, P.; Trivedi, N.; Shukla, M.K.; Gupta, V.; Reddy, C.R.K.; Jha, B. Minerals, PUFAs and antioxidant properties of some tropical seaweeds from Saurashtra coast of India. J. Appl. Phycol. 2011, 23, 797-810. [CrossRef]

26. Matanjun, P.; Mohamed, S.; Mustapha, N.M.; Muhammad, K. Nutrient content of tropical edible seaweeds, Eucheuma cottonii, Caulerpa lentillifera and Sargassum polycystum. J. Appl. Phycol. 2009, 21, 75-80. [CrossRef]

27. Li, B.F. Marine Health Food; Chemical Industry Press: Beijing, China, 2009; pp. 51-72.

28. Moreiras, O.; Carbajal, Á.; Cabrera, L.; Cuadrado, C. Tablas de Composición de Alimentos, 7th ed.; Moreiras, O., Carbajal, Á., Cabrera, L., Cuadrado, C., Eds.; Ediciones Pirámide: Madrid, Spain, 2003.

29. Rao, P.V.S.; Mantri, V.A.; Ganesan, K. Mineral composition of edible seaweed Porphyra vietnamensis. Food Chem. 2007, 102, 215-218. [CrossRef]

30. Allen, L.; de Benoist, B.; Dary, O.; Hurrel, R. Guidelines on Food Fortification with Micronutrientes; World Health Organization and Food and Agriculture Organization of the United Nations: Quebec, QC, CA, 2006.

31. Saini, R.; Badole, S.L.; Zanwar, A.A. Bioactive Dietary Factors and Plant Extracts in Dermatology; Watson, R.R., Zibadi, S., Eds.; Humana Press: Totowa, NJ, USA, 2013; pp. 73-82.

32. FAO/WHO/UNU Expert Consultation. Amino acid requirements of adults. In Protein and Amino Acids Requirements in Human Nutrition; FAO/WHO/UNU: Rome, Italy, 2007; pp. 135-159.

33. Institute of Medicine. Dietary Reference Intakes for Energy, Carbohydrate, Fibre, Fat, Fatty Acids Cholesterol, Protein and Amino Acids; National Academy Press: Washington, DC, USA, 2002.

34. Peng, Y.; Xie, E.; Zheng, K.; Fredimoses, M.; Yang, X.; Zhou, X.; Wang, Y.; Yang, B.; Lin, X.; Liu, J.; et al. Nutritional and chemical composition and antiviral activity of cultivated seaweed Sargassum naozhouense Tseng et Lu. Mar. Drugs 2013, 11, 20-32. [CrossRef] [PubMed] 
35. Ortiz, J.; Romero, N.; Robert, P.; Araya, J.; Lopez-Hernández, J.; Bozzo, C.; Navarrete, E.; Osorio, A.; Rios, A. Dietary fiber, amino acid, fatty acid and tocopherol contents of the edible seaweeds Ulva lactuca and Durvillaea antarctica. Food Chem. 2006, 99, 98-104. [CrossRef]

36. Schmid, M.; Guihéneuf, F.; Stengel, D.B. Fatty acid contents and profiles of 16 macroalgae collected from the Irish Coast at two seasons. J. Appl. Phycol. 2014, 26, 451-463. [CrossRef]

37. ISO. Determination of Moisture Content, ISO 1442:1997 Standard. International Standards Meat and Meat Products; International Organization for Standardization: Genéve, Switzerland, 1997.

38. ISO. Determination of Nitrogen Content, ISO 937:1978 Standard. International Standards Meat and Meat Products; International Organization for Standardization: Genéve, Switzerland, 1978.

39. ISO. Determination of Ash Content, ISO 936:1998 Standard. International Standards Meat and Meat Products; International Organization for Standardization: Genéve, Switzerland, 1998.

40. Shahidi, F.; Synowiecki, J. Nutrient composition of mechanically separated and surimi-like seal meat. Food Chem. 1993, 47, 41-46. [CrossRef]

41. Domínguez, R.; Borrajo, P.; Lorenzo, J.M. The effect of cooking methods on nutritional value of foal meat. J. Food Compos. Anal. 2015, 43, 61-67. [CrossRef]

42. Lorenzo, J.M.; Purriños, L.; Temperán, S.; Bermúdez, R.; Tallón, S.; Franco, D. Physicochemical and nutritional composition of dry-cured duck breast. Poult. Sci. 2011, 90, 931-940. [CrossRef] [PubMed]

(C) 2017 by the authors. Licensee MDPI, Basel, Switzerland. This article is an open access article distributed under the terms and conditions of the Creative Commons Attribution (CC BY) license (http:/ / creativecommons.org/licenses/by/4.0/). 